\title{
THE SORPTION AND POROSITY OF GGBS-PFA TERNARY BLENDED CEMENT CONCRETE
}

\author{
${ }^{1}$ Cheah Chee Ban and ${ }^{2}$ Chow Wee Kang, \\ ${ }^{1,2}$ School of Housing, Building and Planning, Universiti Sains Malaysia 11800, \\ Penang, Malaysia \\ 1'cheahcheeban@usm.my, ${ }^{2}$ cwkang94@outlook.com,
}

\begin{abstract}
Ternary blended concrete is an environmentally friendly alternative to the conventional concrete, using industrial by-product, ground granulated blast furnace slag (GGBS) and pulverized fuel ash (PFA), as partial cement replacement binders of ordinary Portland cement (OPC) in the concrete production. However, the influence of the use of GGBS and PFA at high cement replacement level (up to $80 \%$ by total binder) on the sorption and porosity properties were scarcely explored in prior studies. Hence, this research focuses on the study of influence of cement replacement level from $50 \%$ to $80 \%$ of total mass of binders on the durability properties of flowable high performance concrete. GGBS and PFA are used due to their cementitious properties that similar to ordinary Portland cement that mixed in a ratio of 4:1 in the concrete mix. To achieve the high flowable properties, the ternary blended concrete is designed using a fixed water-to-binder ratio of 0.35 , while the water demand of different mixes is adjusted by the dose of chemical admixtures in order to achieve the desirable concrete flow. The durability properties of designed concrete has been assessed in terms of its permeability, porosity, water absorption and capillary action test. Pozzolanic reaction of alternative binders produces more calcium silicate hydrate $(\mathrm{C}$ $\mathrm{S}-\mathrm{H})$ and calcium aluminate hydrate $(\mathrm{C}-\mathrm{A}-\mathrm{S}-\mathrm{H})$ using excess $\mathrm{SiO}_{2}$ content and $\mathrm{Ca}(\mathrm{OH})_{2}$ produced from the hydration of cement, are expected to impose a positive effect on durability properties of the mixture including reduced permeability and porosity. At the same time making the concrete a low carbon footprint and a sustainable construction material which is more durable for various industrial applications. From the study, the mix proportion that is suitable for production of flowable high performance concrete containing high volume of GGBS and PFA was established.
\end{abstract}

Keywords: Ternary blended concrete; Ground granulated blast furnace slag; Pulverized fuel ash; flowable; High performance concrete; sorption; Permeability; Porosity; Water absorption; Capillary action 


\section{INTRODUCTION}

High demand of Portland cement (OPC) from the market has led to high level of production of cement from limestone. During the production of Portland cement, carbon dioxide, $\mathrm{CO}_{2}$ would emitted into the environment, which causing greenhouse effect, air pollution and global warming. High level of $\mathrm{CO}_{2}$ emission has increased year by year due to rapid development of construction all around the world. Hence, OPC has a very high carbon footprint that gives unexpectable impact to the environment, and this issue must be took seriously.

Hence, the effective way to decrease the encounter the high carbon emission by conventional Portland cement production, ternary blended concrete has introduced. Ternary blended concrete is fabricated using industrial by-product as partial replacement binders or substitute of OPC which exhibited similar or better mechanical, physical and durability properties as compared to OPC concrete[1]. Ground granulated blast furnace slag (GGBS) and pulverized fuel ash (PFA) were chosen due to their ability to react with OPC producing secondary binder phase which enhance the durability and sustainability of concrete[2].

The utilization of these two supplementary cementitious materials is due to its hydrated products, calcium silicate hydrate $(\mathrm{C}-\mathrm{S}-\mathrm{H})$ and calcium aluminate hydrate $(\mathrm{C}-$ A-S-H) by a chemical reaction, called pozzolanic reaction which similar to the $\mathrm{Ca}(\mathrm{OH})_{2}$ from the cement hydration will be produced. The hydration process of ternary blended concrete are divided into primary hydration by Portland cement and GGBS, pozzolanic reaction of GGBS and PFA as the secondary hydration. The pozzolanic reaction is known as ternary blendedization process by GGBS and PFA. They reacts with the $\mathrm{Ca}(\mathrm{OH})_{2}$ produced by cement hydration to form $\mathrm{C}-\mathrm{S}-\mathrm{H}$ bond and C-A-S-H bond that gives a denser microstructure than conventional OPC concrete[3-6]. The denser microstructure has improved the durability properties of ternary blended concrete in term of permeability, porosity, sulphate attack and chloride ingress [7-15].

The denser the microstructure of the concrete, the less permeable the concrete is[5]. The formation of $\mathrm{C}-\mathrm{S}-\mathrm{H}$ produced denser microstructure that harder for sulfate and chloride to penetrate into concrete structure. So, the sulfate and chloride attack is lower when the permeability of the concrete is lower. GGBS and PFA consumes great quantity of $\mathrm{Ca}(\mathrm{OH})_{2}$ which necessary for sulfate attack[10,11,14]. So the possibility of aggressive ion penetration into concrete is lower compared to OPC concrete. Both GGBS and PFA content increase, a less permeable concrete will be produced[8]. However, the ideal replacement level is about up to $40 \%$ of Class F fly ash to the total binder for high strength[6,11]. Whereas the GGBS replacement can used up to $60 \%$ to the total binder[16].

In term of workability, the increase of GGBS will decrease the flow ability of concrete due to the acceleration of the hydration[17] while increase of PFA up to 25\% increase the flow ability of fresh mixture and prevent bleeding and segregation of fresh concrete mixture[14]. 
Due to the benefits of utilization of GGBS and PFA to the concrete, ternary blended high performance concrete can only be produced with the characteristic of high strength and improved durability properties, can be assumed to be more economical by reducing lifetime cycle cost to maintain the concrete structure when come into application for building and infrastructure construction. The design of high performance concrete is such with low w/b ratio of 0.2 to 0.45 , with the use of superplasticizer to adjust the concrete flow and workability.

\section{MATERIALS AND METHODS}

\section{Materials}

The materials used as binder for the mix design of ternary blended concrete are Portland cement, GGBS and PFA, while fine aggregates and coarse aggregates are also added. There are two chemical admixture are used to serve as high range water reducer and high range water reducing retarder. The chemical composition of binders are showed in Table 1.

\section{Portland Cement (OPC)}

The specific gravity of the Portland cement used in the study is 3.15. The typical constituent of Portland cement including calcium oxide $(\mathrm{CaO})$, Silicon dioxide $\left(\mathrm{SiO}_{2}\right)$, Aluminium oxide $\left(\mathrm{Al}_{2} \mathrm{O}_{3}\right)$, ferric oxide $\left(\mathrm{Fe}_{2} \mathrm{O}_{3}\right)$ and sulfur $(\mathrm{VI})$ oxide $\left(\mathrm{SO}_{3}\right)$.

\section{Ground Granulated Blast Furnace Slag (GGBS)}

The GGBS used in the study is obtained from local supplier with the specific gravity of 2.86 and is in granulated form, the specific surface area of GGBS after grinded is found to be an average of $4250 \mathrm{~cm}^{2} / \mathrm{g}$ where would significantly improve the performance of concrete $\left(4000 \mathrm{~cm}^{2} / \mathrm{g}\right.$ to $\left.6000 \mathrm{~cm}^{2} / \mathrm{g}\right)$. GGBS is widely used in concrete industry as supplementary cementitious material to partially replace Portland cement in concrete mix due its similar level of $\mathrm{CaO}$ content that undergoes hydration when reacts with water. The GGBS used is showed in Figure 1.

\section{Pulverized Fuel Ash (PFA)}

The specific surface area of PFA particles used in the study is typically $3000 \mathrm{~cm}^{2} / \mathrm{g}$ and its specific gravity is 2.26 . The fineness of fly ash has offered a better bond formation in the microstructure of the concrete. Besides, use of fly ash results in improve rheology that reduce water demand of concrete which reduces the possibility of bleeding of fresh concrete, hence lower w/c ratio can be achieved with a fixed workability. The PFA used is showed in Figure 2.

Table 1: Chemical composition of binders

\begin{tabular}{lcccccccccccc}
\hline $\begin{array}{l}\text { Sample } \\
(\%)\end{array}$ & $\mathrm{SiO}_{2}$ & $\mathrm{Al}_{2} \mathrm{O}_{3}$ & $\mathrm{Fe} 2 \mathrm{O}_{3}$ & $\begin{array}{c}\mathrm{SiO}_{2}+\mathrm{Al}_{2} \mathrm{O}_{3} \\
+\mathrm{Fe}_{2} \mathrm{O}_{3}\end{array}$ & $\mathrm{CaO}$ & $\mathrm{MgO}$ & $\mathrm{K}_{2} \mathrm{O}$ & $\mathrm{Na}_{2} \mathrm{O}$ & $\mathrm{P}_{2} \mathrm{O}_{5}$ & $\mathrm{TiO}_{2}$ & Chloride & $\begin{array}{c}\text { Loss of } \\
\text { Ignition }\end{array}$ \\
\hline OPC & 22.40 & 3.60 & 2.90 & 28.90 & 65.60 & 1.50 & 0.34 & - & 0.06 & 0.17 & - & 2.53 \\
GGBS & 32.43 & 11.92 & 0.28 & 44.63 & 37.68 & 4.52 & 0.32 & 0.23 & 0.01 & 0.45 & - & - \\
\hline
\end{tabular}




\begin{tabular}{lllllllllllll}
\hline PFA & 43.22 & 17.61 & 13.73 & 74.56 & 11.28 & 5.94 & 0.36 & 0.00 & 0.01 & 0.88 & - & 1.80 \\
\hline
\end{tabular}

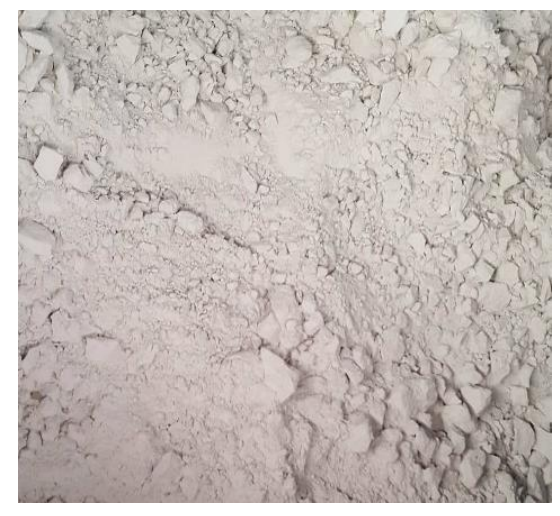

Figure 1: GGBS used in concrete mix

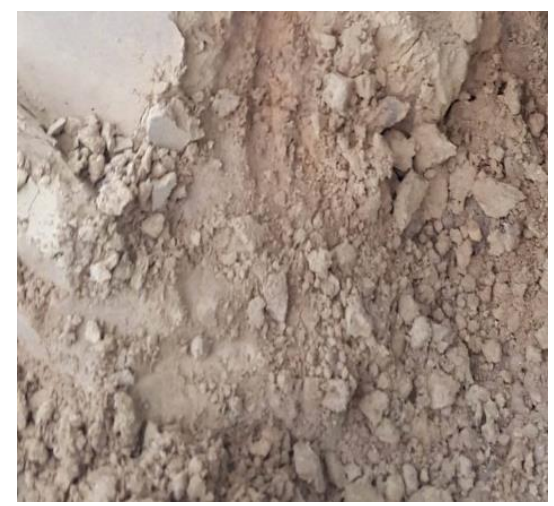

Figure 2: PFA used in concrete mix

\section{Aggregate and Water}

Fine aggregates are obtained from the quarzitic natural river in uncrushed manner with the maximum size about $5 \mathrm{~mm}$ and specific gravity of 2.63 . The fine aggregates is heated to saturated surface dried so it can be ready used for mix. The coarse aggregates is choose to be the maximum size of $5-10 \mathrm{~mm}$ which passed through $10 \mathrm{~mm}$ sieve and retained on the $5 \mathrm{~mm}$ sieve. The specific gravity of coarse aggregates is 2.65 . Then, the coarse aggregates were washed and dried to remove unnecessary debris. Local water source is obtained as the mixing water.

\section{Chemical Admixture}

There are two chemical admixtures, with commercial designation of ACE 8703 and ACE 8109 were added into the mixture during mixing process together with water. The ACE 8703 is served as the slump retention agent in order to achieve required slump without addition of extra water; while the ACE 8109 is the early strength gain accelerator to increase the strength development of the ternary blended concrete in order to achieve the target strength in the early age. The dosage of the SP for each design is showed in the Table 3.4. The flow of the fresh concrete is adjusted by addition 
of extra dosage of SP by $0.05 \%$ to the total binder mass in order to achieve the desired flow of concrete.

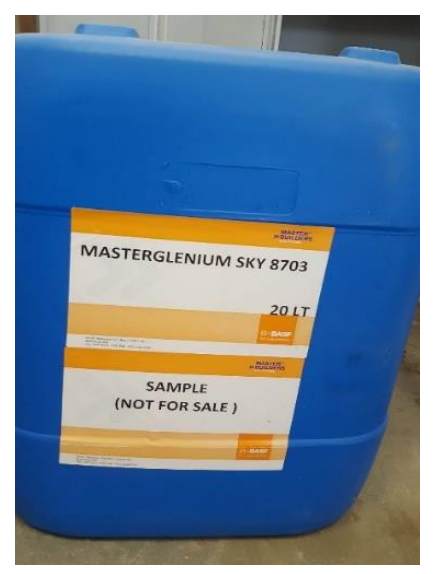

Figure 3: ACE 8703

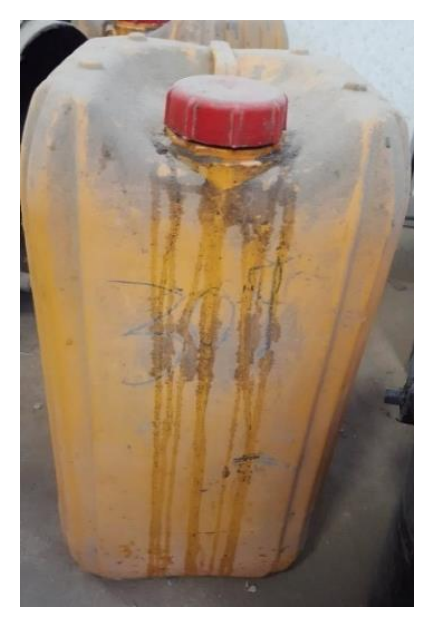

Figure 4: ACE 8109

\section{Testing Instrumentation}

The instruments that were used to prepare, measure and assess the durability properties of fresh and harden concrete including, reusable steel moulds [9 sets of cylindrical specimen $(75 \mathrm{~mm} \varnothing \times 100 \mathrm{~mm}$ high), 9 sets of small cylindrical specimen $(50 \mathrm{~mm} \varnothing \times \mathrm{x}$ $50 \mathrm{~mm}$ high), and 3 sets of $40 \mathrm{~mm} \times 40 \mathrm{~mm} \times 160 \mathrm{~mm}$ prism], concrete mixer, electronic balance (Figure 5), slump cone and flow table, Leed cell permeameter equipped with flow meter (Figure 6), desiccator (Figure 7). 


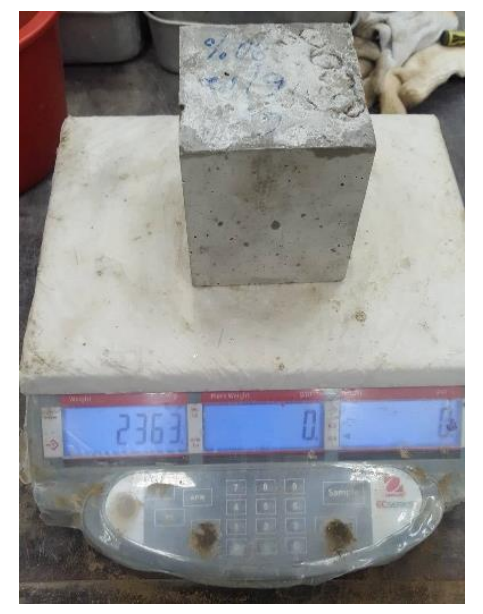

Figure 5: Electronic balance

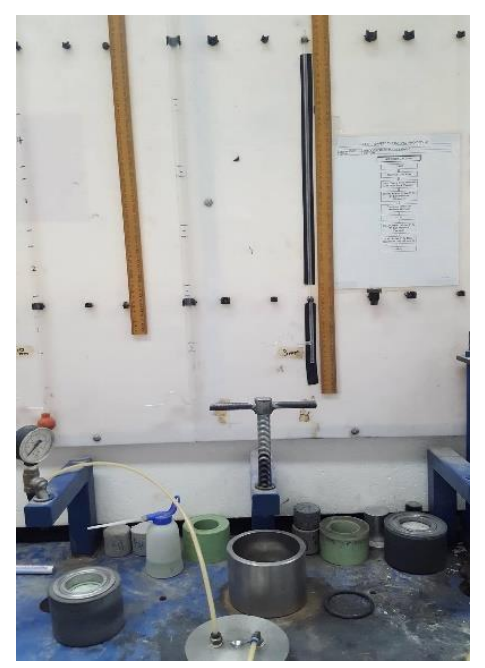

Figure 6: Leed cell permeameter equipped with flow meter

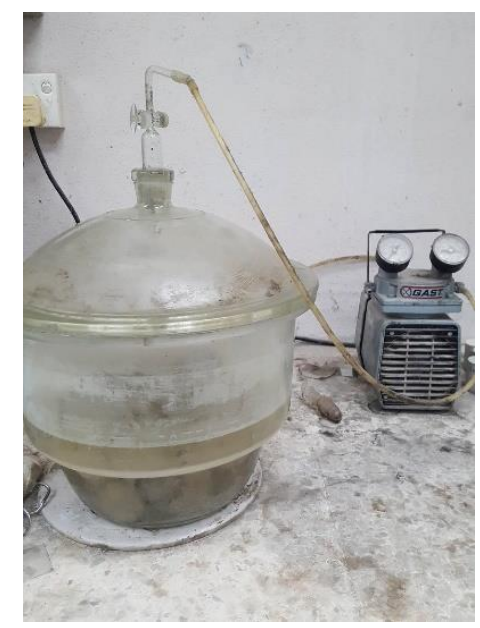

Figure 7: Desiccator for porosity test 


\section{Mix Proportioning}

The mix design of the flowable high performance of concrete is varies based on their replacement level from 50\% up to $80 \%$ where the GGBS: PFA ratio is $4: 1$ and the water content to binder ratio is constant. The water demand for required slump is adjusted by dose of chemical admixtures. The mix designation ratio of the materials of each mix design is showed in Table 2. Table 3 showed the mass of material required for each concrete mix. The percentage of binder and chemical admixture by the total binder mass is showed in Table 4.

Table 2: Mix designation ratio of materials of each mix design

\begin{tabular}{ccccc}
\hline Mix code & Binder & $\begin{array}{c}\text { Coarse } \\
\text { aggregates }\end{array}$ & Fine aggregates & W/b ratio \\
\hline P0 (C) & 1 & 1.68 & 1.98 & 0.35 \\
P50 & 1 & 1.64 & 1.98 & 0.35 \\
P60 & 1 & 1.64 & 1.98 & 0.35 \\
P70 & 1 & 1.63 & 1.98 & 0.35 \\
P80 & 1 & 1.62 & 1.98 & 0.35 \\
\hline
\end{tabular}

Table 3: Mix design for each concrete mix

\begin{tabular}{|c|c|c|c|c|c|c|c|c|c|c|}
\hline \multirow[t]{2}{*}{$\begin{array}{l}\text { Mix } \\
\text { code }\end{array}$} & \multirow[t]{2}{*}{$\begin{array}{c}\text { OPC } \\
\left(\mathrm{kg} / \mathrm{m}^{3}\right)\end{array}$} & \multirow[t]{2}{*}{$\begin{array}{l}\text { GGBS } \\
\left(\mathrm{kg} / \mathrm{m}^{3}\right)\end{array}$} & \multirow[t]{2}{*}{$\begin{array}{c}\text { PFA } \\
\left(\mathrm{kg} / \mathrm{m}^{3}\right)\end{array}$} & \multirow[t]{2}{*}{$\begin{array}{l}\text { Sand } \\
\left(\mathrm{kg} / \mathrm{m}^{3}\right)\end{array}$} & \multirow{2}{*}{$\begin{array}{c}\text { Coarse } \\
\text { aggregate } \\
\left(\mathrm{kg} / \mathrm{m}^{3}\right)\end{array}$} & \multirow[t]{2}{*}{$\begin{array}{l}\text { Water } \\
\left(\mathrm{kg} / \mathrm{m}^{3}\right)\end{array}$} & \multirow[t]{2}{*}{$\begin{array}{l}\text { w/b } \\
\text { ratio }\end{array}$} & \multicolumn{2}{|c|}{$\begin{array}{c}\text { Admixture } \\
\text { (Litre) }\end{array}$} & \multirow[t]{2}{*}{$\begin{array}{l}\text { Flow } \\
(\mathrm{mm})\end{array}$} \\
\hline & & & & & & & & $\begin{array}{l}\text { ACE } \\
8703\end{array}$ & $\begin{array}{l}\text { ACE } \\
8109\end{array}$ & \\
\hline $\begin{array}{l}\text { P0 } \\
\text { (C) }\end{array}$ & 487 & - & - & 964 & 818 & 170 & 0.35 & 4.62 & 6.57 & 460 \\
\hline P50 & 244 & 195 & 49 & 965 & 799 & 170 & 0.35 & 3.65 & 5.60 & 500 \\
\hline P60 & 195 & 234 & 58 & 963 & 798 & 170 & 0.35 & 3.65 & 4.89 & 490 \\
\hline P70 & 146 & 273 & 68 & 964 & 793 & 170 & 0.35 & 3.65 & 4.82 & 440 \\
\hline P80 & 97 & 312 & 78 & 964 & 789 & 170 & 0.35 & 1.95 & 2.73 & 500 \\
\hline
\end{tabular}

Table 4: Percentage of each binders and chemical admixtures by the total binder mass 


\begin{tabular}{ccccccc}
$(\%)$ & $\begin{array}{c}\text { Portland } \\
\text { cement }\end{array}$ & & & & & \\
\hline P0 & 1 & - & - & 0.95 & 1.35 & 0.35 \\
P50 & 0.5 & 0.4 & 0.1 & 0.75 & 1.15 & 0.35 \\
P60 & 0.4 & 0.48 & 0.12 & 0.75 & 1 & 0.35 \\
P70 & 0.3 & 0.56 & 0.14 & 0.75 & 0.99 & 0.35 \\
P80 & 0.2 & 0.64 & 0.16 & 0.4 & 0.56 & 0.35 \\
\hline
\end{tabular}

\section{Specimen Preparation and Curing}

All binders and aggregates are dry mixed in the mixer for 10 minutes in order to mix the materials thoroughly and eventually. Water and chemical admixture were then added into the mixture and mixing for another 2 minutes. Flow test and slump test were carried to ensure the design flow and slump is achieved. If the flow and slump of fresh concrete is undesirable, the extra dosage of $0.05 \%$ to the total mass of binders is added and further mixed until the required flow and slump were achieved. The mixture was then filled into mould sets previously prepared according to the dimension stated above. All the specimens were allowed to cure in the moulds for at least 24 hours then demould for water cure until the testing ages reached.

The replacement level of flowable high performance ternary blended concrete is varies from $50 \%$ to $80 \%$. The concrete mix prepared are P50, P60, P70, P80 and one set of OPC mix as a reference. Total 6 mix design were prepared, Each mix design were casted into 9 sets of cylindrical specimen $(75 \mathrm{~mm} \varnothing \times 100 \mathrm{~mm}$ high), 9 sets of small cylindrical specimen $(50 \mathrm{~mm} \varnothing \times 50 \mathrm{~mm}$ high), and 3 sets of $40 \mathrm{~mm} \times 40 \mathrm{~mm} \times$ $160 \mathrm{~mm}$ prism. A total of 21 sets of specimen for each mix design were tested. The specimens will be tested for following tests:

i. Workability of the fresh concrete that measure the flow diameter of mixture according to BS EN 12350-4:2009[19] and ASTM C143/C143M[20].

ii. Permeability test for $7^{\text {th }}, 28^{\text {th }}, 90^{\text {th }}$ day using cylindrical specimen of $50 \mathrm{~mm} \varnothing$ x 50mm high. [21]

iii. Porosity test for $7^{\text {th }}, 28^{\text {th }}, 90^{\text {th }}$ day using cylindrical specimen of $50 \mathrm{~mm} \varnothing \mathrm{x}$ $50 \mathrm{~mm}$ high.

iv. Water absorption test for $7^{\text {th }}, 28^{\text {th }}, 90^{\text {th }}$ day cylindrical specimen of $\left(75 \mathrm{~mm} \varnothing_{\mathrm{x}}\right.$ 100mm high) according to BS 1881-122[22]..

v. Capillary action test for the first 8 hours and following every 24 hours up to 21 days using standard prism of $40 \mathrm{~mm} \times 40 \mathrm{~mm} \times 160 \mathrm{~mm}$.

\section{Test Methods for Durability Assessment of Concrete}

The intrinsic air permeability of the concrete specimens were determined using Leeds Cell Permeameter proposed by Cabrera and Lynsdale [21]. Meanwhile, the total porosity of the concrete was determined using the test method prescribed in the testing guide RILEM CPC 11.3[23]. The water absorption of the concrete samples were assessed with the standard method as defined in British Standard BS 1881-Part 122. The pore size distribution of the cementitious composites was obtained through the assessment named capillary absorption which was proposed by Benachour et al[24]. 


\section{RESULT AND DISCUSSION}

The results were obtained from the experimental testing on the durability properties of mix design of concrete containing high volume of GGBS and PFA. The results obtained from permeability, porosity, water absorption and capillary action test were analyzed to establish the optimum mix proportion of ternary blended concrete which is suitable for the production of high performance flowable concrete containing high volume of GGBS and PFA as supplementary cementitious materials in term of durability performances.

\section{Air Permeability}

All the ternary blended concrete samples had recorded that the air permeability performance is better than OPC concrete at the final age as shown in Table 5. Although, the OPC sample exhibited highest air permeability resistance at the early age $\left(7^{\text {th }}\right.$ day) among all the sample, but the air permeability of OPC sample was recorded to be lowest at $90^{\text {th }}$ day compared to other ternary blended concrete sample, it showed a significant increase of reading after a long term curing up to 90 days. This phenomenon showed that the hydration rate of OPC sample is faster than those ternary blended concrete sample regardless the replacement level at the early age. A denser concrete was formed by OPC sample due to the formation of hydrated product, calcium hydroxide $\left(\mathrm{Ca}(\mathrm{OH})_{2}\right)$ that forms the pore structure of the OPC concrete while the ternary blended concrete containing less volume of cement to contribute to hydration of cement. Among the ternary blended samples, the P50 sample has the lowest permeability at the early age whereas P60 has highest among the ternary blended samples. At later age, those ternary blended concrete samples has lower air permeability than OPC sample due to the pozzolanic reaction of GGBS and PFA reacts with $\mathrm{Ca}(\mathrm{OH})_{2}$ that produced from cement hydration to form stable calcium silicate hydrate or C-S-H gel that filling the pore of microstructure of ternary blended concrete or reduce in the pore size within pore structure which has increase the permeability resistance[4]. At $90^{\text {th }}$ day testing age, P60 was recorded as the ternary blended sample with highest air permeability resistance. Though P70 and P80 were higher content of GGBS and PFA which might contribute for pozzolanic reaction that to develop the microstructure of the concrete, but low content of Portland cement was gives rise of low percentage of $\mathrm{Ca}(\mathrm{OH})_{2}$ content which can be used for formation of C-S-H and CA-S-H gel. The formation of these bond by GGBS and PFA consumes a larger quantity of $\mathrm{Ca}(\mathrm{OH})_{2}$. Hence, P50 and P60 are less permeable than P70 and P80. The air permeability of $\mathrm{P} 50$ and $\mathrm{P} 60$ at $90^{\text {th }}$ day is $1.53 \times 10^{-17} \mathrm{~m}^{2}$ and $1.18 \times 10^{-17} \mathrm{~m}^{2}$ respectively. The value of P50 and P60 is 65-73\% lower than OPC sample. The optimum percentage of replacement is $50-60 \%$ in term of the permeability performance of the concrete.

Table 5: Air permeability

\begin{tabular}{cccc}
\hline \multirow{2}{*}{ Mix code } & \multicolumn{3}{c}{ Test day $\left(\times 10^{-17}\right)$} \\
\cline { 2 - 4 } 7th day & 28th day & 90th day \\
\hline P0 & 4.38 & 3.53 & 2.96
\end{tabular}




\begin{tabular}{llll} 
P50 & 4.45 & 4.23 & 1.53 \\
P60 & 3.98 & 3.21 & 1.18 \\
P70 & 4.39 & 4.14 & 3.48 \\
P80 & 4.02 & 3.16 & 2.47 \\
\hline
\end{tabular}

\section{Porosity}

At the early age, all of the ternary blended concrete samples has lower porosity than OPC sample, except P50 with a slight higher porosity that recorded as $10.66 \%$ compared with $10.48 \%$ for OPC sample. As the age of concrete grow, porosity of all samples were reduced due to further hydration of binders. For decrease in porosity of ternary blended concrete samples is due to the secondary hydration of supplementary cementitious materials, GGBS and PFA which has finer particles than Portland cement that contribute to the formation of $\mathrm{C}-\mathrm{S}-\mathrm{H}$ and $\mathrm{C}-\mathrm{S}-\mathrm{A}-\mathrm{H}$ bond that filling the pores between of the hydrated product from the primary hydration of Portland cement.

Besides, P50 has higher porosity than those with higher replacement level of Portland cement at all testing age. During $90^{\text {th }}$ day testing age, the total porosity of P50 is higher than other ternary blended samples which possess $7.69 \%$, but lower than OPC sample with $9.76 \%$. Hence, it showed that ternary blended concrete has better porosity resistance than OPC sample, and the replacement level higher than 50\% replacement possess better porosity performance. Among the all the ternary blended samples, P60 obtained the lowest porosity value at all testing age which is only $4.36 \%$ that is $55 \%$ lesser than reference mix which is $9.76 \%$. The results is showed in Figure 8. Hence, the porosity of concrete is lower when ternary blended concrete containing $60-80 \%$ GGBS and PFA.

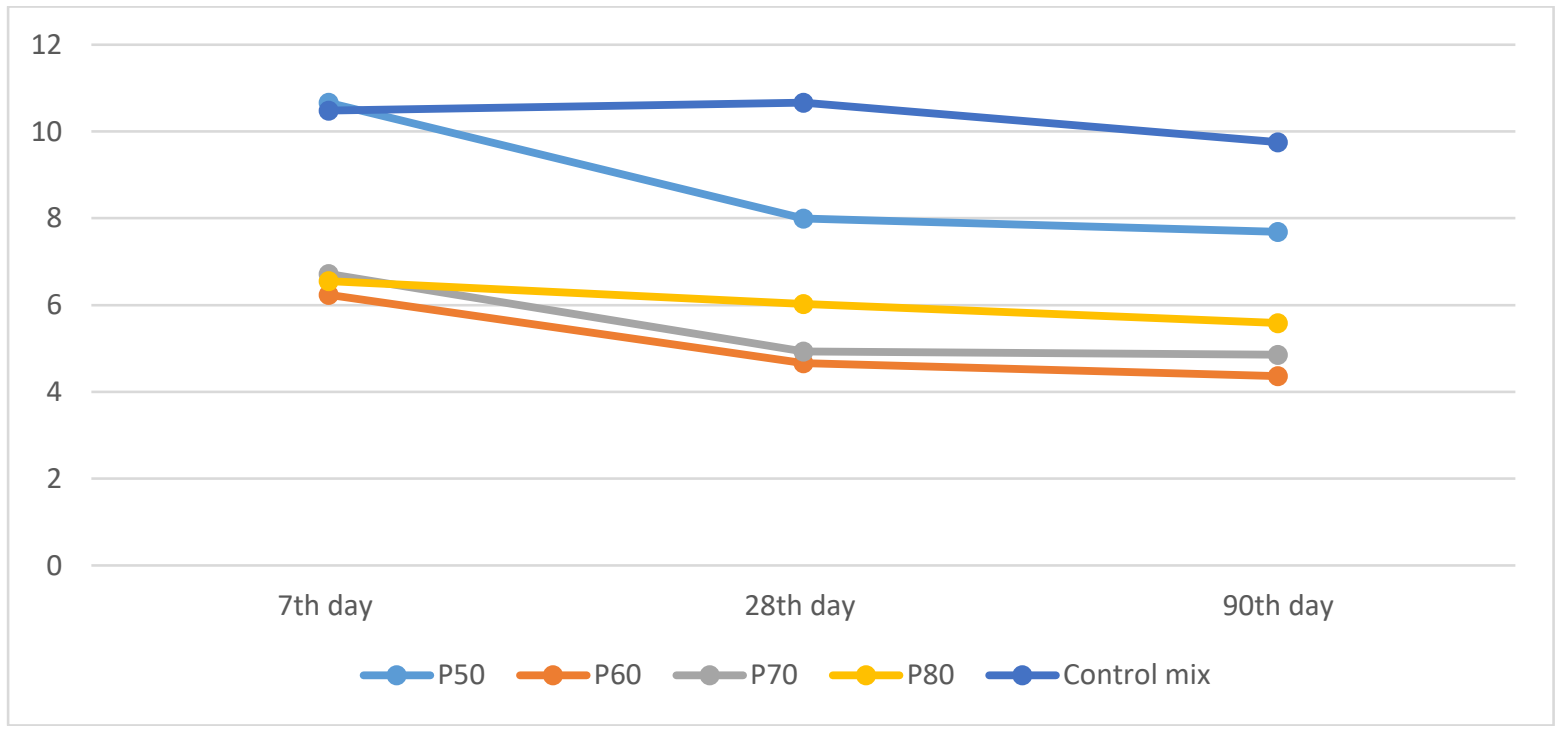

Figure 8: Porosity 


\section{Water Absorption}

In Figure 9, the water absorption of ternary blended concrete mix at all level of replacement, $50 \%-80 \%$ by GGBS and PFA were recorded and plotted, exhibited lesser sorptivity than OPC sample as the reference mix. All samples obtained a reduction of water absorption value over the time after long term curing process. At early age, OPC has highest water absorption than other ternary blended concrete samples, which is $2.26 \%$ and the lowest value, $0.63 \%$ for P60. This results indicated that ternary blended concrete containing high volume of GGBS and PFA can possesses less sorptivity than OPC concrete. However, P60 with $60 \%$ of replacement level by GGBS and PFA with the percentage of $48 \%$ and $12 \%$ by the total mass of binders has the lowest water absorption value at all age. This is due to less void volume of the pore structure of concrete by means of formation of C-S-H bond and C-A-S-H bond from the reaction of GGBS and PFA with the $\mathrm{Ca}(\mathrm{OH})_{2}$ produced from hydration of Portland cement which has enhance the resistance for water penetration[3]. The higher water absorption value of P70 and P80 might because of less formation of hydrated products by cement hydration and more relying on ternary blendedization of GGBS and PFA for the microstructure formation. At the $90^{\text {th }}$ day, the water absorption value of P60 has recorded as $0.43 \%$ which is almost four times lesser than OPC sample with the value of $1.67 \%$. This results is supported by the study stated that ideal fly ash replacement level is $15 \%$ to $25 \%$ for high strength concrete [6]. The surface water absorption of the concrete is lowest when the replacement level is $60 \%-70 \%$.

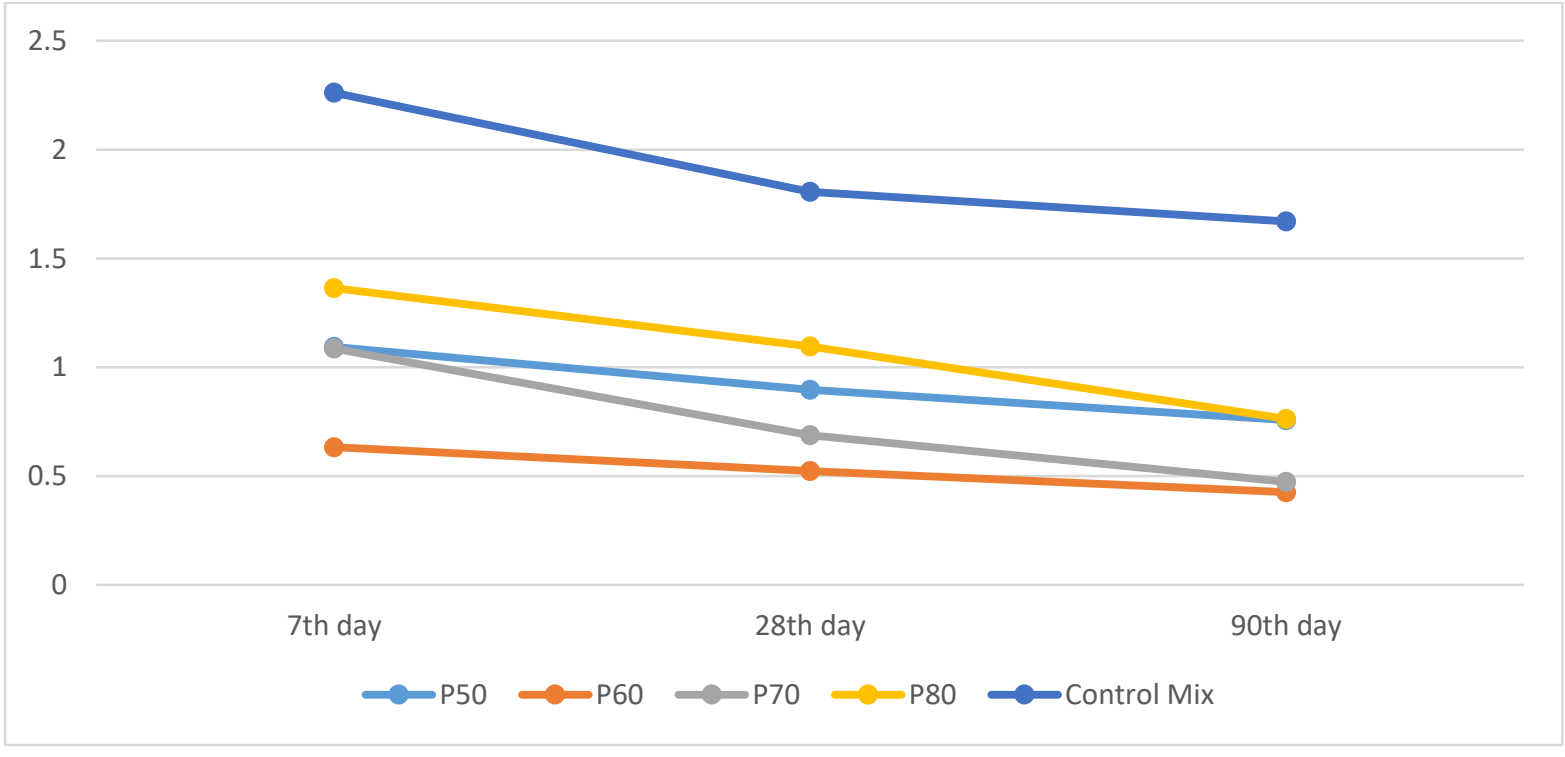

Figure 9: Water absorption 


\section{Capillary Action}

The results of capillary action of all samples were showed in the Figure 10 using their cumulative weight gain against the square root of time by hours. All samples experienced rapid weight gain in first 8 hours, especially at the $2^{\text {nd }}$ hour to $3^{\text {rd }}$ hour, that was a drastically gain in weight. Same phenomenon happened during the $2^{\text {nd }}$ day to $3^{\text {rd }}$ day for all sample while the OPC sample and P50 showed a significant jump in the weight compared to other ternary blended samples which are steadier with a gain of less than $0.1 \%$. The high cumulative weight gain in first 4 hours can be interpreted that water was being absorbs by the concrete where filling the bigger capillary pores with higher pore diameter within those specimens and then the increase of the cumulative weight gain becoming steady because of macro-pores within the microstructure of concrete was completely filled by water, the later water absorption is filling those finer and smaller micro-pores up to $14^{\text {th }}$ day [18]. The cumulative weight gain became more linear for all concrete samples after 14 days. The OPC sample showed a steeper gradient of cumulative weight gain over time due to the existence of more capillary macro-pores than ternary blended concrete with high replacement level. In the other words, this indicates that ternary blended concrete containing high volume of GGBS and PFA has more micro-pores than macro-pores compared with OPC sample. Hence, the presence of GGBS and PFA do reduces the pore size of the capillary pores within the microstructure of the concrete.

From the Figure 11, the cumulative weight gain of OPC sample at the end of the capillary action test is relatively highest with the reading of $42.83 \mathrm{~kg} / \mathrm{m}^{3}$ which is $27 \%$ higher than P50 and 56-59\% higher than other ternary blended concrete samples. Among those ternary blended concrete, P50 has steeper increase in the gradient of the cumulative weight gain of concrete over the period comparing with the other ternary blended, P60, P70 and P80. The cumulative weight of P50 at last testing age is 44\% higher than P60, the lowest cumulative weight gain at the moment. This indicates that the replacement of Portland cement by GGBS and PFA more than 60\% has significantly improve the capillary penetration resistance of concrete. The replacement of Portland cement by GGBS and PFA up to $60 \%$ has a better capillary penetration resistance comparing with other samples which is only $17.58 \mathrm{~kg} / \mathrm{m}^{3}$. The capillary transport of P60 is 2.4 times better than OPC samples at $90^{\text {th }}$ day. 


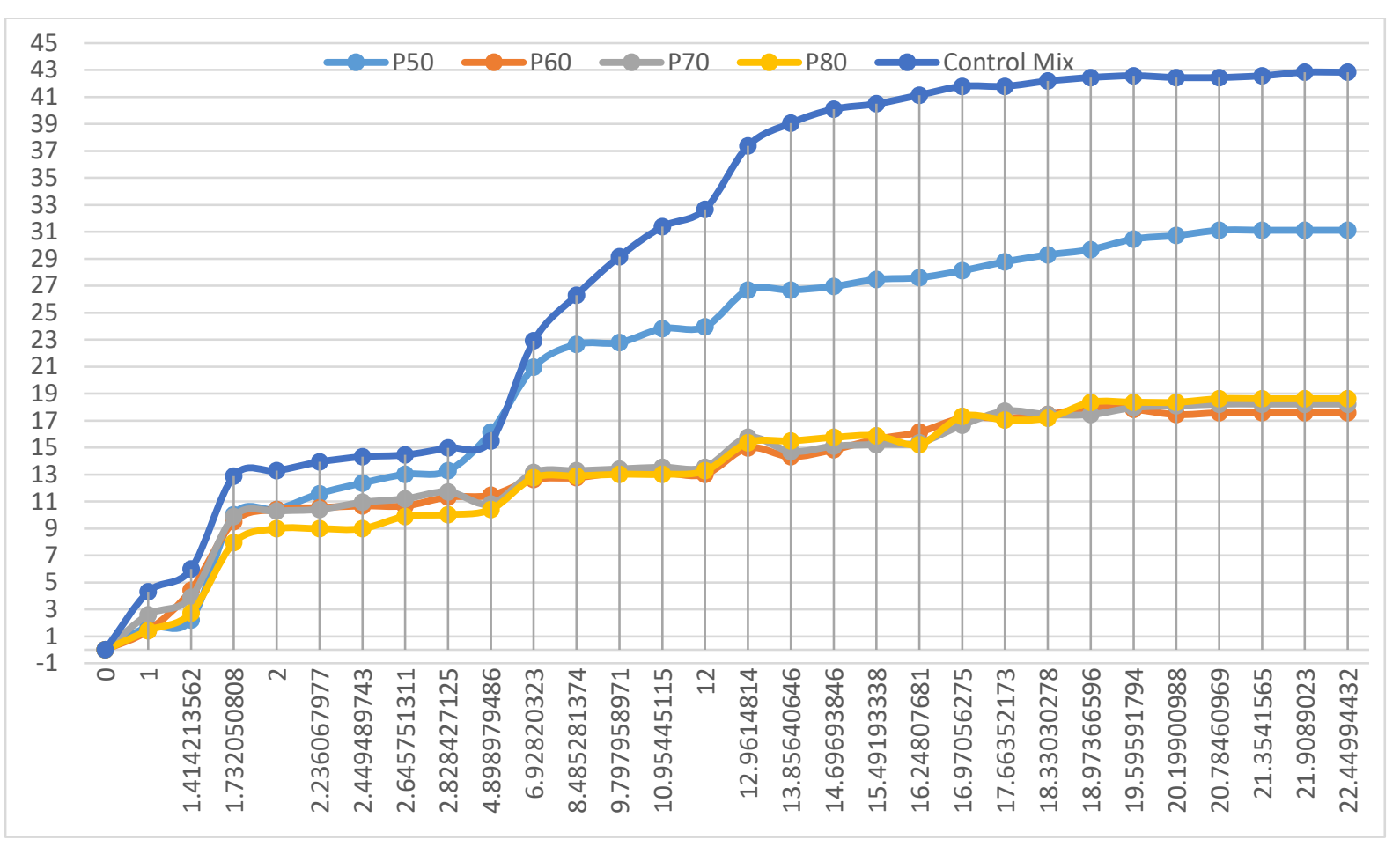

Figure 10: Capillary action

\section{CONCLUSION}

Based on the analysis of data obtained from laboratory investigation done on the durability properties of high performance concrete mix design with various percentages of cement replacement by GGBS and PFA, the conclusion of research can be derived as follows:

- Low permeability concrete is produced when high percentage of GGBS and PFA is used to replace OPC as binder. The mix design with 50-60\% replacement has $65-73 \%$ less permeable than OPC concrete at $90^{\text {th }}$ day. Meanwhile, the replacement level more than $60 \%$ do not increase the permeability of concrete significantly.

- The replacement level increase from $50 \%$ to $60 \%$ significantly reduces both micro and macro pores of concrete as shown by the capillary absorption results. The porosity of ternary blended concrete containing 60\% GGBS and PFA is lowest, and it is 55\% lower than OPC concrete.

- A concrete with lower porosity is produced when containing 60-80\% of GGBSPFA hybrid supplementary binder.The surface water absorption decreased to the lowest at 60-70\% replacement of Portland cement, which is almost four times lower than OPC mix.

- The replacement level more than 50\% showed significant decrease in capillary transport, while P60, P70 and P80 showed similar degree of capillary transport. 
P60 has lowest capillary transport among the other ternary blended concrete, is 2.4 times lower than OPC concrete.

- Concrete with replacement level more than 50\% has significant improvement in the durability performance and a perceivable drop of performance when the replacement was increase up to $80 \%$. The P60 with $60 \%$ replacement by GGSS and PFA is the optimum mix proportion of concrete with improved durability properties.

\section{REFERENCE}

[1] Part Wei Ken, Mahyuddin Ramli, Cheah Chee Ban, 2015. An overview on the influence of various factors on the properties of ternary blended concrete derived from industrial by-products. Construction and Building Materials, Volume 77, pp. 370-395.

[2] Fernando Pacheco-Torgal, Joao Castro-Gomes, Said Jalali, 2008. Alkaliactivated briders: A review Part 1. Historical background, terminology, reaction mechanisms and hydration products. Construction and Building Materials, Volume 22, pp. 1305-1314.

[3] Aggregate Industries, 2013. Fly Ash - BSEN 450. [Online] Available at: http://cms.esi.info/Media/documents/77639_1380029864006.pdf [Accessed 22 February 2017].

[4] Richardson, D. N., 2006. Organizational results research report - Strength and durability of a $70 \%$ ground granulated blast furnace slag concrete mix, s.l.: s.n.

[5] Peter W.C. Leung, H.D. Wong, January 2011. Final report on durability and strength development of ground granulated blastfurnace slag concrete (Geo report No. 258), Homantin, Kowloon, Hong Kong: Geotechnical Engineering Office, Hong Kong.

[6] ACI committe 211, 2008. Guide for selecting proportions for high strength concrete with Portland cement and other cementitous materials. In: ACI Structural Journal. s.1.:Materials journal, pp. 272-283.

[7] T.Bakharev, J.G. Sanjayan, Y.B. Cheng, 2011. Resistance of alkali-activated slag concrete to carbonation. Cement and Concrete Research, Volume 31, pp. 1277-83.

[8] Osbome, G., 1991. The sulfate resistance of Portland and blast furnace slag cement concretes. Montreal, Canada, Special Publication, pp. 1047-71.

[9] J. Deja and J. Malotepszy, 1989. Resistance of alkali-activated slag mortars to. Trondheim, s.n., pp. 1547-63.

[10] Jagmeet Singh, Harpreet Singh, Rajindervir Singh, November,2015. Portland slag cement using ground granulated blast furnace slag (GGBFS) - A review. International Journal of Research in Engineering and Applied Sciences (IMPACT FACTOR - 5.981), 5(11), pp. 47-53.

[11] P. Nath \& P. Sarker, 2011. Effect of fly ash on the durability properties of high strength concrete. Procedia Engineeing, Volume 14, pp. 1147-56. 
[12] P.J. Tikalsky, R.L. Carrasquillo, 1989. The effect of fly ash on sulfate resistance of concrete, Austin: Research Report 3-5/9-87-481, Durability and Performance of Concrete Containing Fly Ash.

[13] Jun Liu, Guangfeng Ou, Qiwen Qiu, Xiaochi Chen, Jing Hong, Feng Xin, 2017. Chloride transport and micorstructure of concrete with/without fly ash under atmospheric chloride condition. Construction and Building Materials, Volume 146, pp. 493-501.

[14] Peng Zhang, Qingfu Li, 2013. Effect of Fly Ash on Durability of High Performance Concrete Composites. Research Journal of Applied Sciences, Engineering and Technology, 6(1), pp. 7-12.

[15] Aires Camões, José B. Aguiar, Said Jalali, 2003. Durability of Low Cost High Performance Fly Ash Concrete.

[16] Della M. Roy, Weimin Jiang, M.R. Silsbee, 2000. Chloride diffusion in ordinary, blended, and alkali-actived cement pastes and its relation to other properties. Cement and Concrete Research, Volume 30, pp. 1879-1884.

[17] Pradip Nath, Prabir Kumar Sarker, 2014. Effect of GGBFS on setting, workability and early strength properties of fly ash ternary blended concrete cured in ambient condition. Construction and Building Materials, Volume 66, pp. 163-171.

[18] Y. Benachour, C.A. Davy, F. Skoczylas, H. Houar, 2008. Effect of a high calcite filler addition upon microstructural, mechanical, shrinkage and transport properties of a mortar. Cement and Concrete Research, Volume 38, pp. 727-736.

[19] BS EN 12350-4:2009, 2009. Testing fresh Concrete. Degree of compactability. London: Bristish Standards.

[20] ASTM Standard C143/ C143M-15a, 1997. Standard Test Method For Slump of Hydraulic-Cement Concrete. West Conshohocken, PA: ASTM International.

[21] J. G. Cabrera, C. J. Lynsdale, 1988. A new gas permeameter for measuring the permeability of mortar and concrete. Magazine of Concrete Research, September, 40(144), pp. 177-182.

[22] BS 1881-122:2011, 2011. Testing concrete. Method for determination of water absorption. London: British Standards.

[23] RILEM, 1984. Absorption of water by immersion under vacuum. Materials and Structures. RILEM CPC 11.3, 101,p. 393-394.

[24] Benachour, Y., Davy, C. A., Skoczylas, F. \& Houari, H., 2008. Effect of a high calcite filler addition upon microstructural, mechanical, shrinkage and transport properties of a mortar. Cement and Concrete Research, 38 (6),p. 727-736. 